\title{
SEJARAH \\ PEMBANGUNAN HUKUM PERBANKAN SYARIAH DI INDONESIA
}

\author{
Khotibul Umam \\ Fakultas Hukum, Universitas Gajah Mada \\ email: khotibulumam@ugm.ac.id
}

disampaikan 18/12/2019 - di-review 10/5/2020 - diterima 03/12/2020

DOI: $10.25123 /$ vej.3629

\begin{abstract}
In this article the author traces the historic development of Islamic or sharia banking in Indonesia and this will be done by analysing the evolution of a series of successive laws promulgated over time. From these laws (Law Nos. 7/1992; 10/1998 and 21/2008) we can discern, how over the years, the Indonesian government gradually accept and recognized sharia banking principles, resulting in the establishment of Sharia Banks alongside conventional Banks. These successive laws also shows the gradual process of policy changes which involves a top-down, bottom up and again a top down approach. Through this process, Sharia Banks develops in Indonesia and has been able to meet society's need not only for a modern banking system, but also more importantly, providing banking services in line with the sharia.
\end{abstract}

Keywords: sharia bank, historic development, modern banking, sharia principles.

\begin{abstract}
Abstrak
Tulisan ini akan menelaah sejarah perkembangan perbankan syariah di Indonesia dengan menelusuri rangkaian peraturan perundang-undangan yang melandasinya. Dari sejumlah peraturan perundang-undangan yang berturut-turut muncul (UU No. 7/1992; UU No. 10/1998 dan UU 21/2008) dapat kita cermati perkembangan pengakuan dan penerimaan perbankan syariah di Indonesia. Tahapan perkembangan ini sekaligus menunjukkan pengembangan kebijakan pemerintah yang bersifat top-down, bottom up dan top-down secara simultan. Melalui tahapantahapan ini pada akhirnya di Indonesia berkembang sistem perbankan syariah yang yang mampu memenuhi kebutuhan masyarakat tidak saja akan jasa perbankan modern, namun jasa perbankan yang memenuhi prinsip syariah.
\end{abstract}

Kata Kunci: perbankan syariah, sejarah perkembangan, perbankan modern, prinsip syariah

\section{Pendahuluan}

Perbankan merupakan lembaga keuangan yang sangat berperan penting bagi pembangunan suatu negara. Dalam Pasal 1 angka 2 Undang-Undang Nomor 10 Tahun 1998 tentang Perubahan Atas Undang-Undang Nomor 7 Tahun 1992 tentang Perbankan (selanjutnya disingkat UUP 1998) Bank didefinisikan sebagai badan usaha yang menghimpun dana dari masyarakat dalam bentuk simpanan 
dan menyalurkannya kepada masyarakat dalam bentuk kredit dan atau bentukbentuk lainnya dalam rangka meningkatkan taraf hidup rakyat banyak. ${ }^{1}$

Akan tetapi, umat Islam di Indonesia sebagian besar masih belum dapat menerima bank, bukan karena tidak percaya akan arti pentingnya bank bagi pembangunan akan tetapi karena bank-bank dimaksud mendasarkan pada sistem bunga (interest based). Bunga oleh sebagian besar umat Islam dianggap merupakan riba yang secara jelas dan tegas dilarang oleh ajaran Islam sebagaimana tertuang dalam Al-Quran dan Hadist Nabi Muhammad SAW.

Bagi umat Islam di Indonesia adanya pendapat bahwa bunga bank sama dengan riba dipertegas dengan keluarnya Fatwa Majelis Ulama Indonesia (MUI) tentang keharaman bunga bank yang merupakan hasil lokakarya para ulama tentang bunga bank dan perbankan di Cisarua, Bogor tanggal 19-22 Agustus 1990. Dalam lokakarya tersebut sebenarnya muncul dua pandangan yang berbeda terhadap bunga bank, yakni: (1) pendapat yang menyatakan bahwa bunga bank itu riba dan oleh karena itu hukumnya haram; (2) pendapat bahwa bunga bank bukan riba dan oleh karena itu diperbolehkan, dengan alasan rukshah. ${ }^{2}$ Fatwa tersebut kemudian dipertegas lagi dalam Keputusan Fatwa Majelis Ulama Indonesia Nomor 1 Tahun 2004 tentang Bunga (Interest atau Fa'iddah), yang memutuskan bahwa praktik pembungaan uang saat ini telah memenuhi kriteria riba yang terjadi pada zaman Rasulullah SAW, yaitu riba nasiah. Oleh karena itu praktik pembungaan uang termasuk salah satu bentuk riba dan haram hukumnya, baik yang dilakukan oleh bank, asuransi, pasar modal, pegadaian, koperasi dan lembaga keuangan lainnya maupun oleh individu.

Dengan demikian yang menjadi kritik Islam terhadap perbankan konvensional bukan dalam hal fungsinya sebagai lembaga intermediasi keuangan, akan tetapi karena di dalam operasionalnya terdapat unsur yang dilarang, yakni bunga (interest). Di samping itu dimungkinkan adanya unsur lain berupa

$1 \quad$ Undang-Undang R.I., No. 10 Tahun 1998, Perubahan Atas Undang-Undang Nomor 7 Tahun 1992 tentang Perbankan, , L.N.R.I. Tahun 1998 No. 182, Pasal 1 angka 2.

2 Zainul Arifin, Memahami Bank Syariah: Lingkup, Peluang, dan Prospek, Alvabet, Jakarta, 1999, hlm., 27. 
perjudian (maysir), ketidakpastian/keraguan (gharar), dan unsur kebatilan. ${ }^{3}$ Islam menawarkan akad-akad tradisional Islam untuk menggantikan unsur-unsur dimaksud sebagai dasar dalam operasional perbankan atau yang dalam bahasa undang-undang dikenal dengan istilah prinsip syariah.

Perbankan syariah sebagai elemen penting dalam hukum perbankan di Indonesia saat ini mengalami perkembangan yang pesat, dimana adanya didukung oleh terbitnya berbagai regulasi yang mengatur kelembagaan, kegiatan usaha, serta cara dan proses dalam melaksanakan kegiatan usaha tersebut. Prinsip utama bank syariah terdiri dari larangan atas riba pada semua jenis transaksi; pelaksanaan aktivitas bisnis atas dasar kesetaraan (equality), keadilan (fairness) dan keterbukaan (transparency); pembentukan kemitraan yang saling menguntungkan; serta keharusan memperoleh keuntungan usaha secara halal. ${ }^{4}$

Terkait dengan dimulainya sejarah pembangunan hukum perbankan syariah di Indonesia secara garis besar dapat disimak dalam buku yang secara khusus memotret perkembangan perbankan syariah di Asia Tenggara. Dalam buku itu disebutkan bahwa :

The present government in Indonesia seems to associate Islamic Banking with Islamic fundamentalism to which the regime is not at all sympathetic. In order to accommodate the public demand for the existence of a new banking system, the Indonesia Government has implicitly allowed the Shariah banking operations in the Act No. 7 of 1992 concerning banking which is elucidated in the Government Decree No. 72 of 1992 concerning Bank Applying Share Base Principles. The set of regulations have served as legal foundations for Shari'ah banking operations in Indonesia (the new era of dual banking system). ${ }^{5}$

Menurut Wirdyaningsih, hingga terbitnya UUP 1998, Indonesia telah melewati dua tahapan pembinaan, yaitu "tahapan perkenalan" (introduction) yang ditandai dengan diberlakukannya Undang-Undang Nomor 7 Tahun 1992

3 Abdul Ghofur Anshori, Kuliah Perdana Magister Hukum Bisnis dan Kenegaraan, Perkembangan Hukum, Kelembagaan, dan Operasional Perbankan Syariah di Indonesia, Fakultas Hukum UGM, Yogyakarta, 14 Juni 2008, 2008, hlm., 1.

4 Institut Bankir Indonesia, Konsep, Produk dan Implementasi Operasional Bank Syariah, Penerbit Djambatan, Jakarta, 2001, hlm., 23.

5 Angelo M. Venardos, Islamic Banking \& Finance in South-East Asia : Its Development \& Future, World Scientific Publishing, New Jersey-London-Singapore-Beijing-Shanghai-Hongkong-TaipeiChennai, 2005, hlm., 177. 
(selanjutnya disingkat UUP 1992) dan "tahapan pengakuan" (recognition) yang ditandai dengan diberlakukannya UUP 1998. Tahapan yang dikehendaki berikutnya adalah "tahapan pemurnian" (purification) yang nanti akan ditandai dengan diberlakukannya undang-undang yang khusus mengatur perbankan syariah. ${ }^{6}$ Undang-undang dimaksud, yakni Undang-Undang Nomor 21 Tahun 2008 tentang Perbankan Syariah (selanjutnya disingkat UUPS) yang merupakan lex specialis dari UUP 1998.

Tahap pembangunan hukum perbankan syariah di Indonesia tersebut ternyata hampir sama dengan yang terjadi di Malaysia yang terbagi menjadi tiga tahapan, yakni disovery phase, acceptance phase, dan dominant phase. Hal ini sebagaimana dinyatakan oleh Tan Sri Nor Mohamed Yakcop:

".... Three practical phase for the development of Islamic finance in Malaysia, i.e. the first phase was that of discovery, and the second phase was that of acceptance, beginning in 2003, when there already existed a huge increase in utilizing Islamic financial principles as a tool of competitive advantage. Phase three would be the dominance of Islamic financial institutions over the conventional." 7

Berdasarkan informasi tersebut terlihat bahwa baik di Indonesia maupun di Malaysia, hukum mampu menempatkan diri sebagai sarana pembangunan. Hukum sebagai salah satu sarana bagi pembangunan mendapatkan pijakan teoritisnya dalam pernyataan Mochtar Kusumaatmadja, yakni bahwa hukum adalah sarana perubahan, ia tidak hanya sebagai kaidah, akan tetapi sebagai sarana pembangunan. ${ }^{8}$ Para pengikutnya menamakan teori yang disampaikan oleh Mochtar Kusumaatmadja tersebut sebagai Teori Hukum Pembangunan, yang pada hakikatnya lebih kepada teori tentang politik hukum. Akibatnya teori ini lebih berkaitan dengan kebijakan pemerintah di bidang hukum (legal policy) yang

6 Wirdyaningsih-dkk, Bank dan Asuransi Islam di Indonesia, Kerja sama Kencana Media Group dan Fakultas Hukum Universitas Indonesia, Jakarta, 2005, hlm., 3.

7 Mohamed Yakcop dalam Zaharuddin Abd. Rahman, Contemporary Islamic Finance Architecture, IBFIM, Kuala Lumpur, Malaysia, 2014, hlm., 4

8 Nina Pane, Rekam Jejak Kebangsaan Mochtar Kusumaatmadja, Penerbit Buku Kompas, Jakarta, 2015, hlm., 139 dan 170 
dilakukan secara top-down, bottom-up, dan kembali ke top-down secara simultan. ${ }^{9}$ Teori ini tepat dijadikan sebagai pisau analisis bagi pembangungan hukum perbankan syariah di Indonesia, karena secara realitas empiris didirikannya bank syariah pertama kali merupakan respon Pemerintah terhadap fatwa MUI mengenai bunga bank (top-down), kesuksesan bank syariah dalam menghadapi krisis 1998 (bottom-up) yang kemudian mendorong Pemerintah melalui otoritas perbankan mengeluarkan aneka peraturan perundang-undangan guna mengembangkan industri perbankan syariah di Indonesia (top-down). Demikian seterusnya hingga diundangkannya Undang-Undang Nomor 21 Tahun 2008 tentang Perbankan Syariah dengan dimunculkannya berbagai lembaga hukum di dalamnya sebagai respon terhadap munculnya kekurangpercayaan masyarakat terhadap industri perbankan syariah ketika secara hukum dan kelembagaan masih menjadi satu dengan perbankan konvensional (bottom up).

Berdasarkan latar belakang tersebut, tulisan ini memfokuskan diri pada pertanyaan sentral, yakni bagaimana hukum berperan dalam pembangunan sistem perbankan syariah di Indonesia, baik pada tahap perkenalan, pengakuan, dan pemurnian, serta apa saja penanda adanya signifikansi diundangkannya peraturan perundang-undangan dalam setiap tahapan dimaksud yang menunjukkan adanya perubahan sebagai karakter utama dari proses pembangunan? Guna menjawab permasalahan dimaksud, maka dilakukan penelitian hukum normatif dengan pendekatan peraturan perundang-undangan (statute approach), pendekatan sejarah (historical approach), dan pendekatan komparatif (comparative approach). ${ }^{10}$

\section{Pembahasan}

\section{Pembangunan Hukum di Tahap Perkenalan (Introduction Phase)}

Pada dasarnya entitas bank syariah di Indonesia sudah dimulai sejak tahun 1983 dengan keluarnya Paket Desember 1983 (Pakdes 83) yang berisi sejumlah regulasi di bidang perbankan, dimana salah satunya ada peraturan yang

9 Shidarta (ed), Mochtar Kusumaatmadja dam Teori Hukum Pembangunan: Eksistensi dan Implikasi, Epsitema Institute dan Huma, Jakarta, 2012, hlm. 67 dan hlm., 72.

10 Peter Mahmud Marzuki, Penelitian Hukum: Edisi Revisi, Kencana, Jakarta, 2005, hlm., 133. 
memperbolehkan bank memberikan kredit dengan bunga $0 \%$ (zero interest). Baru pada tahun 1991 berdirilah Bank Muamalat Indonesia (BMI) sebagai bank umum satu-satunya yang melaksanakan kegiatan usaha berdasarkan prinsip bagi hasil. Pendirian BMI merupakan salah satu rekomendasi konkrit dari lokakarya "Bunga Bank dan Perbankan" yang diselenggarakan MUI pada tanggal 18-20 Agustus 1990 di Cisarua. Ide ini kemudian dipertegas melalui Munas IV MUI di Hotel Sahid Jaya Jakarta tanggal 22-25 Agustus 1990. Salah satu amanah dari Munas IV MUI tersebut adalah perlunya pendirian Bank Islam di Indonesia. ${ }^{11}$

Operasional BMI pada awal pendiriannya lebih mendasarkan pada normanorma hukum Islam di bidang muamalah dimana transaksi tidak berbasis bunga (riba), adanya zakat, pelarangan produksi barang dan jasa yang tidak sesuai sistem nilai islam berdasarkan halal haram, tidak boleh ada maysir (judi) dan gharar (ketidakpastian). ${ }^{12}$ Introduksi bank berdasarkan prinsip bagi hasil dalam hukum positif sebagai respon Pemerintah terhadap fatwa bunga bank dan pendirian BMI, yakni melalui pengundangan UUP 1992 dan Peraturan Pemerintah Nomor 72 Tahun 1992 tentang Bank Berdasarkan Prinsip Bagi Hasil (selanjutnya disingkat PPBH 1992). ${ }^{13}$

Pada era ini berdasarkan Pasal 6 PPBH 1992 bank hanya diperbolehkan melaksanakan satu jenis kegiatan secara konvensional atau secara bagi hasil. Implikasi pengaturan yang demikian, yakni bahwa layanan syariah hanya dapat dilaksanakan oleh Bank Umum atau Bank Perkreditan Rakyat yang semata-mata melaksanakan kegiatan usahanya berdasarkan prinsip syariah, atau dalam hal ini secara teknis yuridis dikenal dengan Bank Berdasarkan Prinsip Bagi Hasil.

Berbeda dengan Indonesia, Malaysia telah memasuki discovery phase ini di tahun 1983 yang ditandai dengan pendirian Bank Islam Malaysia sebagai single bank. Terdapat tiga elemen dasar dalam sistem perbankan Islam di Malaysia, yakni: (1) a large number of instrument; (2) a large number of institutions; (3) an 
Islamic interbank money market. ${ }^{14}$ Kebijakan di Malaysia berlangsung secara topdown dengan menyiapkan kerangka hukum dan kelembagaan yang komprehensif di awal pengenalan sistem perbankan Islam.

Signifikansi dari UUP 1992 dan peraturan pelaksanaannya sebagai sarana pembangunan hukum perbankan syariah di Indonesia, yakni bahwa Pemerintah melalui sarana hukum melegitimasi berdirinya bank bagi hasil dan sekaligus memperkenalkan kepada masyarakat bahwa kegiatan intermediasi keuangan dapat dilaksanakan baik berdasarkan sistem bunga bank atau sistem bagi hasil sehingga dapat menjadi alternatif bagi masyarakat untuk mendapatkan layanan perbankan yang sejalan dengan fatwa MUI.

\section{Pembangunan Hukum di Tahap Pengakuan (Recognition Phase)}

Tahap pengakuan ditandai dengan diundangkannya UUP 1998. Dalam UUP 1998 telah diberikan pengakuan secara tegas terhadap eksistensi bank syariah. Hal ini nampak pada pengertian/definisi Bank Umum dan Bank Perkreditan Rakyat. Bank Umum adalah bank yang melaksanakan kegiatan usaha secara konvensional dan atau berdasarkan Prinsip Syariah yang dalam kegiatannya memberikan jasa dalam lalu lintas pembayaran. Sementara Bank Perkreditan Rakyat adalah bank yang melaksanakan kegiatan usaha secara konvensional atau berdasarkan Prinsip Syariah yang dalam kegiatannya tidak memberikan jasa dalam lalu lintas pembayaran. ${ }^{15}$

Dari pengertian tersebut menunjukkan bahwa Indonesia semakin mantab menganut kebijakan sistem perbankan ganda (dual bangking system). Hal ini sebagaimana disampaikan oleh Rifki Ismal dalam karyanya :

Indonesia applies dual economic and banking system. The central bank act number 23 of 1999 amended by act number 3 of 2004, stated that the country operates both Islamic and conventional monetary operations. Also, the banking act number 7 of 1992 and amended by act number 10 of 1998 allows the implementation of Islamic banking along with the conventional one. ${ }^{16}$

\footnotetext{
14 Zaharuddin Abd. Rahman, Supra No 7, hlm., 2.

15 Lihat Undang-Undang R.I., No. 10 Tahun 1998, Perubahan Atas Undang-Undang Nomor 7 Tahun 1992 tentang Perbankan, , L.N.R.I. Tahun 1998 No. 182, Pasal 1 angka 2.

16 Rifki Ismal, The Indonesian Islamic Bankin : Theory and Practices, Gramata Publishing, Jakarta, 2011, hlm., 1.
} 
Fase ini semakin menunjukkan adanya peningkatan komitmen pemerintah terhadap perbankan syariah secara top down dengan memberikan landasan hukum yang kuat dengan mengizinkan perbankan konvensional membuka unit usaha syariah (UUS). ${ }^{17}$ Hal ini menyebabkan perkembangan bank syariah di Indonesia berlangsung lebih cepat daripada sebelumnya. Bank-bank umum konvensional pasca UUP 1998 mulai memberikan layanan syariah melalui mekanisme Islamic Window, antara lain yaitu PT. Bank Rakyat Indonesia (Persero) “Tbk”, PT. Bank Negara Indonesia 1946 (Persero) “Tbk”, dan PT. Bank Permata. 18

Di tataran operasional, pada tahap pengakuan ini Bank Indonesia selaku otoritas yang mengatur dan mengawasi industri perbankan syariah telah menerbitkan PBI No. 7/46/PBI/2005 tentang Akad Penghimpunan Dan Penyaluran Dana Bagi Bank Yang Melaksanakan Kegiatan Usaha Berdasarkan Prinsip Syariah. Terbitnya PBI ini dimaksudkan agar setiap pelaku dalam industri perbankan syariah, termasuk pengelola bank/pemilik dana/pengguna dana, serta otoritas pengawas harus memiliki kesamaan cara pandang terhadap Akad-Akad produk penghimpunan dan penyaluran dana bank syariah. ${ }^{19}$

PBI 7/46/PBI/2005 memiliki kelemahan, yakni belum mengatur kegiatan perbankan syariah di bidang jasa. Oleh karena itu, pada tahun 2007, PBI tentang akad dimaksud kemudian dicabut dan diganti dengan PBI No. 9/19/PBI/2007 tentang Pelaksanaan Prinsip Syariah Dalam Kegiatan Penghimpunan Dana Dan Penyaluran Dana Serta Pelayanan Jasa Bank Syariah. Dalam PBI No. 9/19/PBI/2007, kegiatan usaha perbankan syariah dilakukan dalam bentuk sebagai berikut:

a. dalam kegiatan penghimpunan dana dengan mempergunakan antara lain Akad Wadi'ah dan Mudharabah;

b. dalam kegiatan peyaluran dana berupa Pembiayaan dengan mempergunakan antara lain Akad Mudharabah, Musyarakah,

17 Hirsanuddin, Hukum Perbankan Syariah di Indonesia: Pembiayaan Bisnis dengan Prinsip Kemitraan, Genta Press, Yogyakarta, 2008, hlm., 154.

18 Peri Umar Farouk, t.t. Sejarah Hukum Perbankan Syariah Indonesia, http://www.sharialearn. com/ diakses 9 Desember 2014.

19 Bagian menimbang Peraturan Bank Indonesia No. 7/46/PBI/2005, Akad Penghimpunan dan Penyaluran Dana Bagi Bank Yang Melaksanakan Usaha Berdasarkan Prinsip Syariah, L.N.R.I. Tahun 2005 No. 124 DPbS, Tambahan Lembaran Negara Republik Indonesia Nomor 4563 
Murabahah, Salam, Istishna', Ijarah, Ijarah Muntahiya Bittamlik dan Qardh; dan

c. dalam kegiatan pelayanan jasa dengan mempergunakan antara lain Akad Kafalah, Hawalah, dan Sharf. ${ }^{20}$

Kemudian secara kelembagaan, kemudahan dalam rangka pemberian layanan syariah yakni diperkenalkannya konsep Islamic Window. Perubahan Pasal 6 huruf m oleh UUP 1998 terhadap UUP 1992, menjadi jendela bagi pembukaan kantor bank yang melaksanakan kegiatan usaha berdasarkan prinsip syariah oleh Bank Umum Konvensional.

Selain konsep Islamic Window, terdapat mekanisme office chaneling. Office Channelling merupakan istilah yang diberikan guna menandai dimungkinkannya melakukan kegiatan usaha perbankan berdasarkan prinsip syariah di Kantor Cabang dan/atau Kantor Cabang Pembantu Bank Umum Konvensional. Praktik perbankan syariah sebenarnya tidak diperkenankan dilakukan bersama-sama dalam satu kantor yang berpraktik secara konvensional. Akan tetapi hal ini dibenarkan berdasarkan Pasal 38 ayat 2 PBI No. 8/3/PBI/2006, yakni dengan menggunakan pola kerjasama.

Kedua lembaga hukum inilah (islamic window dan office chanelling) yang menurut hemat penulis berimplikasi bagi perkembangan yang signifikan layanan jasa bank syariah di Indonesia. Hal ini dikarenakan secara hukum telah diberikan kesempatan bagi bank konvesional, khususnya bank umum untuk memberikan layanan syariah. BUK yang memiliki UUS tidak perlu direpotkan untuk mendirikan Kantor Cabang/Kantor Cabang Pembantu/Kantor Kas yang khusus memberikan layanan syariah, melainkan dapat menjadi satu dengan kantor konvensionalnya.

Munculnya Undang-Undang Nomor 40 Tahun 2007 tentang Perseroan Terbatas (UUPT) juga berkontribusi bagi perkembangan bank syariah, khususnya dalam rangka pembentukan BUS, sebagai bank yang murni syariah. Hal ini terlihat

20 Lihat Peraturan Bank Indonesia No. 9/19/PBI/2007, Pelaksanaan Prinsip Syariah Dalam Kegiatan Penghimpunan Dana Dan Penyaluran Dana Serta Pelayanan Jasa Bank Syariah, L.N.R.I. Tahun 2007 No. 165, Tambahan Lembaran Negara Republik Indonesia Nomor 4793, Pasal 2 jo Pasal 3. 
pada ketentuan mengenai penggabungan, peleburan, pengambilalihan, dan pemisahan sebuah legal entity.

Praktik yang terjadi di era UUP 1998, yakni mulai terbentuknya beberapa BUS baru dengan jalan pengambilalihan (akuisisi) diikuti dengan perubahan (konversi) kegiatan usaha dari konvensional menjadi syariah. Contoh konkritnya yakni terjadinya akuisisi terhadap PT. Bank Susila Bakti oleh PT. Bank Mandiri (Persero) Tbk yang kemudian dikonversi menjadi Bank Syariah Mandiri. ${ }^{21} \mathrm{Hal}$ serupa juga dilakukan oleh PT. Bank Mega yang membeli Bank Tugu sebagai bank konvensional untuk kemudian dikonversi menjadi syariah. ${ }^{22}$

Hal serupa terjadi di Malaysia, pada accepatance phase yang dimulai tahun 1993 ini dilakukan perluasan kelembagaan yang dapat menawarkan layanan keuangan Islam (the large number of institutions offering Islamic financial services). Ada dua alternatif yang diberikan, yakni: (a) Establishing new Islamic banks; or (b) allowing the conventional banking system to also offer Islamic banking services. ${ }^{23}$ Kebolehan lembaga perbankan konvensional memberikan layanan syariah melalui Islamic window ini sama dengan di Indonesia dengan konsep UUS.

Dengan demikian signifikansi diundangkannya UUP 1998 sebagai penanda tahap pengakuan terbukti secara empiris menjadikan perkembangan dan pertumbuhan perbankan syariah atau setidak-tidaknya layanan bank berbasis syariah meningkat secara lebih pesat. Layanan syariah dapat diberikan oleh BUS, BPRS, dan BUK yang memiliki UUS. Kemudahan pemberian layanan syariah via peraturan perundang-undangan di bidang perbankan (top-down) ini ternyata masih menyisakan sejumlah persoalan, terutama dari sisi pengaturan dan kelembagaan yang oleh sebagian masyarakat dianggap berdampak pada belum optimalnya bank syariah dalam melaksanakan prinsip syariah, terutama dari

21 Bank Syariah Mandiri, Laporan Tahunan 2013 PT Bank Syariah Mandiri, Bank Syariah Mandiri, Jakarta, 2013, hlm., 29.

22 Bank Mega Syariah, Laporan Tahunan Bank Mega Syariah 2011, Bank Mega Syariah, Jakarta, 2011, hlm., 7.

23 Zaharuddin Abd. Rahman, Supra No 7, hlm. 2. 
layanan syariah yang dilakukan oleh entitas konvensional. ${ }^{24}$ Hal ini dianggap sebagai pendorong perlunya undang-undang khusus yang mengatur secara kelembagaan, kegiatan usaha, serta cara dan proses melaksanakan kegiatan usaha oleh entitas perbankan syariah.

\section{Pembangunan Hukum di Tahap Pemurnian (Purification Phase)}

Kebutuhan akan adanya undang-undang yang khusus mengatur perbankan syariah terealisasi pada tahun 2008. Pada tahun ini ada 2 (dua) undang-undang yang terkait erat dengan ekonomi syariah, yakni Undang-Undang Nomor 19 Tahun 2008 tentang Surat Berharga Syariah Negara (UU SBSN) dan UUPS.

Pada tataran makro, Bank Indonesia telah merumuskan sebuah Grand Strategy Pengembangan Pasar Perbankan Syariah berupa: penetapan visi 2010 untuk menjadikan Industri Perbankan Syariah Indonesia menjadi yang terkemuka di ASEAN, pembentukan citra baru perbankan syariah nasional yang bersifat inklusif dan universal, pemetaan pasar secara lebih akurat, pengembangan produk yang lebih beragam, peningkatan layanan, serta strategi komunikasi baru yang memposisikan perbankan syariah lebih dari sekedar bank (beyond banking). ${ }^{25}$

Berdasarkan UUPS, kegiatan perbankan berdasarkan prinsip syariah secara kelembagaan dapat dilakukan melalui tiga institusi, yaitu: (1) Bank Umum Syariah/BUS; (2) Unit Usaha Syariah/UUS; dan (3) Bank Pembiayaan Rakyat Syariah/BPRS. Perkembangan BUS, UUS, dan BPRS mengalami perkembangan yang cukup signifikan pasca UUPS, sebagaimana terlihat dalam statistik OJK per 30 September 2019 tercatat terdapat 14 (empat belas) BUS, 20 (dua puluh) UUS, dan 130 (seratus tiga puluh) BPRS. ${ }^{26}$

24 Hanif Amali Rivai dkk, "Identifikasi Faktor Penentu Keputusan Konsumen Dalam Memilih Jasa Perbankan : Bank Syariah Vs Bank Konvensional", Penelitian Bank Indonesia, Jakarta, 6 Maret 2016.

25 Otoritas Jasa Keuangan, "Kebijakan Pengembangan Perbankan Syariah di Indonesia", artikel pada laman Otoritas Jasa Keuangan, Jakarta, http://ojk.go.id/bank-syariah, diakses 18 Desember 2014.

26 Otoritas Jasa Keuangan, 2019, Statistik Perbankan Syariah September 2019, https://www.ojk.go.id/id/kanal/syariah/data-dan-statistik/statistik-perbankan-syariah/ Documents/Pages/Stastistik-Perbankan-Syariah---September-2019/Statistik\%20 Perbankan\%20Syariah\%20September\%202019.pdf, diakses 16 Desember 2019. 
Berdasarkan UUPS, menurut Sutan Remy Sjahdeini telah ditetapkan bahwa bank-bank syariah Indonesia (baca: BUS, UUS, dan BPRS), tidak boleh melakukan kegiatan usaha yang melanggar Prinsip Syariah. Prinsip Syariah yang harus dipatuhi oleh bank-bank syariah menurut UUPS adalah Prinsip Syariah yang telah difatwakan oleh Dewan Syariah Nasional - Majelis Ulama Indonesia (DSN-MUI) dan selanjutnya telah telah dituangkan dalam Peraturan Bank Indonesia (PBI, kini POJK). Lebih lanjut Sutan Remy Sjahdeini menyebut prinsip ini sebagai Prinsip Syariah Perbankan dan telah menjadi hukum positif karena adanya penunjukan oleh UUPS sebagai sesuatu yang wajib dilaksanakan oleh bank syariah maupun UUS. Pelanggaran terhadap Prinsip Syariah Perbankan akan mengakibatkan akadakad yang dibuat antara Bank Syariah dan nasabah menjadi batal demi hukum (null and void). ${ }^{27}$

Dengan mendasarkan pada Pasal 4 UUPS, maka Bank Syariah dan UUS sebagaimana Bank Konvensional merupakan lembaga intermediasi keuangan (financial intermediary institution). Lebih lanjut dilekatkan fungsi sosial yang bersifat fakultatif, yakni dengan mendasarkan antara lain pada Undang-Undang Nomor 41 Tahun 2004 tentang Wakaf dan Undang-Undang Nomor 23 Tahun 2011 tentang Pengelolaan Zakat.

Realiasi atas fungsi intermediasi keuangan diwujudkan dalam berbagai produk perbankan syariah yang diperuntukkan bagi nasabah. Produk bank syariah terangkum dalam daftar produk yang dikeluarkan Bank Indonesia dan kini daftar kodifikasi produk Bank Syariah dan UUS dikeluarkan oleh Otoriras Jasa Keuangan (OJK). Produk-produk tersebut didasarkan pada akad-akad tradisional Islam atau prinsip syariah. Prinsip dimaksud menurut Muhammad Syafii Antonio terdiri dari prinsip titipan atau simpanan (depository/al-wadi'ah), bagi hasil (profit-sharing), jual beli (sale and purchase), sewa (operational lease and financial lease), dan jasa (fee based services). ${ }^{28}$ Realisasi fungsi perbankan syariah di ranah sosial, karena sifatnya fakultatif, maka sangat digantungkan pada kebijakan dari

27 Sutan Remy Sjahdeini, Perbankan Syariah: Produk-Produk dan Aspek-Aspek Hukumnya, Kencana Prenada Media, Jakarta, 2014, hlm., 2-3.

28 Muhammad Syafi'i Antonio, Bank Syariah dari Teori ke Praktik, Gema Insani Press dan Tazkia Cendekia, Jakarta, 2001, hlm., 83. 
bank syariah yang bersangkutan. Bank syariah dalam hal ini dapat berperan sebagai unit pengumpul zakat dan lembaga keuangan syariah penerima wakaf uang.

Era UUPS merupakan era atau tahapan penting dalam rangka lebih memurnikan operasional bank syariah. Pengaturan yang ditujukan ke arah pemurnian dimaksud menurut Penulis, antara lain yakni adanya amanah tentang pembentukan Komite Perbankan Syariah (KPS), pengaturan perubahan (konversi) bank konvensional menjadi bank syariah, dan pengaturan mengenai adanya kewajiban melakukan pemisahan (spin-off) UUS Bank Umum Konvensional.

Keberadaan KPS, konversi bank konvensional menjadi bank syariah, dan adanya kewajiban pemisahan UUS yang ada dalam UUPS secara konkrit juga menjadi fokus OJK dalam pengembangan industri perbankan syariah, yakni menjadi bagian yang direncanakan secara komprehensif melalui Roadmap Perbankan Syariah 2015-2019 yang ditujukan sebagai upaya meningkatkan kembali pertumbuhan kegiatan usaha perbankan syariah dan mencapai visi untuk memberikan kontribusi yang signifikan terhadap perekonomian nasional. Roadmap ini memuat isu-isu strategis dan arah kebijakan pengembangan perbankan syariah. Isu-isu tersebut terdiri dari: (1) belum selarasnya visi dan kurangnya koordinasi antar pemerintah dan otoritas dalam pengembangan perbankan syariah; (2) Modal yang belum memadai, skala industri dan individual bank yang masih kecil serta efisiensi yang rendah; (3) biaya dana yang mahal yang berdampak pada keterbatasan segmen pembiayaan; (4) produk yang tidak variatif dan pelayanan yang belum sesuai ekspektasi masyarakat; (5) kuantitas dan kualitas SDM yang belum memadai serta teknologi informasi yang belum dapat mendukung pengembangan produk dan layanan; (6) pemahaman dan kesadaran masyarakat yang masih rendah; dan (7) pengaturan dan pengawasan yang belum optimal. Guna merespon isu-isu strategis tersebut, OJK telah menetapkan 7 (tujuh) arah kebijakan yang meliputi: (1) memperkuat sinergi kebijakan antara otoritas dengan pemerintah dan stakeholders lainnya; (2) memperkuat permodalan dan skala usaha serta memperbaiki efisiensi; (3) memperbaiki struktur dana untuk mendukung perluasan segmen pembiayaan; (4) memperbaiki kualitas dan 
layanan produk; (5) memperbaiki kuantitas dan kualitas SDM, TI, serta infrastruktur lainnya; (6) meningkatkan literasi dan preferensi masyarakat; dan (7) memperkuat serta harmonisasi pengaturan dan pengawasan. ${ }^{29}$

Dari ketujuh isu dan arah kebijakan dalam rangka pengembangan perbankan syariah tersebut, keberadaan KPS, perubahan bank konvensional menjadi bank syariah, dan pemisahan (spin-off) UUS BUK termuat dalam isu dan arah kebijakan nomor (1), (2), dan (7). Dari ketiga isu dan arah kebijakan tersebut, antara lain memuat rencana konkrit berupa: (1) pembentukan forum kerjasama dengan lembaga terkait dalam rangka penyusunan referensi hukum dan peraturan perundang-undangan yang lebih mengakomodasi prinsip syariah ${ }^{30}$, antara lain menurut Penulis dapat dilakukan dengan forum KPS yang sudah bertransformasi menjadi Komite Pengembangan Jasa Keuangan Syariah (KPJKS), yang pembahasannya bisa diperluas dengan menggandeng pihak lain melalui Working Group Perbankan Syariah; (2) Penyusanan Roadmap Spin-Off UUS, mendorong pembetukan BUMN/BUMD syariah, dan penyempurnaan kebijakan modal inti minimum dan klasifikasi BUKU BUS;31 dan (3) Penyempurnaan peraturan terkait kelembagaan BUS dan panduan pengawasan \& perizinan atas kelembagaan tersebut. ${ }^{32}$

Dengan luasnya arah kebijakan OJK dalam rangka pengembangan perbankakan syariah tersebut, maka tulisan ini membatasi pada: (1) keberadaan KPS; (2) perubahan (konversi) bank konvensional menjadi bank syariah; dan (3) pemisahan UUS BUK. Ketiga lembaga hukum tersebut menurut Penulis dapat dijadikan sebagai sarana pembangunan hukum perbankan syariah dalam rangka mencapai tujuan utama dari keberadaan perbankan syariah itu sendiri, yakni menunjang pelaksanaan pembangunan nasional dalam rangka meningkatkan

\footnotetext{
29 Departemen Perbankan Syariah, “Roadmap Perbankan Syariah Indonesia 2015-2019”, Otoritas Jasa Keuangan, 2015, hlm. x-xi.

30 Id., hlm. 29

31 Id., hlm. 31-32

32 Id., hlm. 42
} 
keadilan, kebersamaan, dan pemerataan kesejahteraan rakyat. ${ }^{33}$ Penjelasan dari ketiga hal tersebut, yakni sebagai berikut:

\section{Komite Perbankan Syariah (KPS)}

Komite Perbankan Syariah sebagaimana yang diamanatkan UUPS, telah mendapatkan peraturan operasionalnya berupa PBI No. 10/32/PBI/2008 tentang Komite Perbankan Syariah. Dalam Pasal 1 angka 1 PBI dimaksud disebutkan bahwa Komite Perbankan Syariah, yang selanjutnya disebut Komite adalah forum yang beranggotakan para ahli di bidang syariah muamalah dan/atau ahli ekonomi, ahli keuangan, dan ahli perbankan, yang bertugas membantu Bank Indonesia dalam mengimplementasikan fatwa Majelis Ulama Indonesia menjadi ketentuan yang akan dituangkan ke dalam Peraturan Bank Indonesia.

Tugas Komite secara spesifik adalah membantu Bank Indonesia dalam: (a) menafsirkan fatwa MUI yang terkait dengan perbankan syariah; (b) memberikan masukan dalam rangka implementasi ke dalam Peraturan Bank Indonesia; (c) melakukan pengembangan industri perbankan syariah. Hasil pelaksanaan tugas dimaksud akan disampaikan kepada Bank Indonesia dalam bentuk rekomendasi. ${ }^{34}$

Pasca OJK efektif melaksanakan tugasnya di bidang pengaturan dan pengawasan perbankan, keberadaan dari KPS berdasarkan laporan perkembangan keuangan syariah 2013 yang diterbitkan 0JK disebutkan bahwa dengan terbentuknya OJK selaku otoritas pengawasan jasa keuangan, fungsi dan tugas KPS termasuk yang diamanahkan untuk dialihkan kepada OJK yang mana sesuai dengan lingkup kewenangannya mencakup keseluruhan industri keuangan konvensional dan syariah yang tidak hanya meliputi sektor perbankan namun juga industri keuangan non bank (IKNB) dan Pasar Modal, sehingga di OJK KPS diformulasikan dalam bentuk Komite Pengembangan Jasa Keuangan Syariah (KPJKS) 0JK. ${ }^{35}$ Secara yuridis eksistensi KPJKS merupakan manifestasi dari

33 Lihat Pasal 3 Undang-Undang Nomor 21 Tahun 2008 tentang Perbankan Syariah.

34 Lihat Pasal 5 PBI No. 10/32/PBI/2008, Komite Perbankan Syariah, L.N.R.I Tahun 2008 No. 179 DPbS, Tambahan L.N.R.I. No. 4927.

35 Otoritas Jasa Keuangan, Laporan Perkembangan Keuangan Syariah Tahun 2013, https://www.ojk.go.id/id/data-dan-statistik/ojk/Pages/laporan-perkembangan-keuangansyariah-2013.aspx, diakses 6 Januari 2015, hlm., 103. 
amanat pembentukan Komite Perbankan Syariah (KPS) sebagai amanah dari Pasal 26 Undang-Undang Nomor 21 Tahun 2008 tentang Perbankan Syariah, yang mana menurut Pasal 69 UU OJK, fungsi dan tugas Bank Indonesia terkait dengan KPS dialihkan kepada fungsi dan tugas OJK. ${ }^{36}$

Tujuan pembentukan KPJKS adalah membantu OJK dalam mengimplementasikan fatwa MUI dan mengembangkan jasa keuangan syariah. Tugas KPJKS dalam membantu OJK sama seperti tugas KPS dalam membantu Bank Indonesia. Hanya saja KPJKS memberikan masukan terkait dengan pembentukan POJK bukan PBI. Hasil pelaksanaan tugas KPJKS disampaikan kepada OJK dalam bentuk rekomendasi KPJKS. Dalam rangka mendukung efektivitas pelaksanaan tugasnya, KPJKS dibantu oleh Tim Kerja KPJKS yang terdiri dari internal OJK dan eksternal OJK dari berbagai keahlian dan kepakaran terkait. Tim Kerja yang melaksanakan fungsi analisis dan pendalaman berbagai isu dan permasalahan pengembangan keuangan syariah nasional yang selanjutnya akan dipaparkan di dalam rapat KPJKS. 37

Peran KPJKS dalam melakukan interpretasi dan harmonisasi fatwa DSNMUI bagi pembentukan POJK di bidang keuangan syariah, yakni memberikan rekomendasi bagi OJK atas hasil penelaahan fatwa DSN-MUI. Pembahasan terhadap suatu fatwa dilakukan melalui forum Working Group Perbankan Syariah (WGPS) yang melibatkan multistakeholders, yakni OJK, DSN-MUI, Mahkamah Agung RI, DSAS-IAI, dan KPJKS. Guna memastikan adanya linearitas antara fatwa dan regulasi keuangan syariah, maka dilakukan konsultasi timbal balik dalam proses penyusunan fatwa dan regulasi dimaksud memalui forum WGPS. ${ }^{38}$

36 Pembentukan KPJKS melalui Keputusan Rapat Dewan Komisioner (RDK) OJK No. 120/MS1/2013 tanggal 18 Desember 2013. Realisasi dari RDK, yakni dengan diterbitkannya PDK No. 47/PDK.02/2013 tanggal 30 Desember 2013 tentang KPJKS di OJK. Dalam PDK tersebut diatur bahwa KPJKS bertanggung jawab kepada Dewan Komisioner OJK. Keanggotaan KPJKS terdiri dari unsur OJK, Kementerian Agama, MUI, dan unsur masyarakat lainnya dengan komposisi berimbang.

37 Otoritas Jasa Keuangan, Supra No 35, hlm., 104.

38 Khotibul Umam, "Transformasi Fatwa Dewan Syariah Nasional - Majelis Ulama Indonesia ke dalam Regulasi Keuangan Syariah", Laporan Penelitian Doktor 2019 yang belum dipublikasikan, Unit Riset dan Publikasi Fakultas Hukum UGM, Yogyakarta, 2019, hlm., 92. 
Dengan demikian menurut Penulis, kehadiran KPS (Kini KPJKS) akan memberikan kemudahan bagi regulator (OJK) dalam mengimplementasikan fatwa yang dikeluarkan DSN-MUI. Keanggotaan KPJKS dari berbagai unsur akan lebih mampu menghadirkan prinsip syariah Islam di bidang ekonomi yang abstrak menjadi sesuatu yang konkrit dan implementatif. Hal ini juga sejalan dengan Roadmap Perbankan Syariah, khususnya dalam rangka penyusunan referensi hukum dan peraturan perundang-undangan yang lebih mengakomodasi prinsip syariah, namun dengan tetap memperhatikan aspek hukum dan aspek operasional perbankan syariah.

\section{Perubahan (Konversi) Bank Konvensional menjadi Bank Syariah}

Perubahan dari Bank Konvensional menjadi Bank Syariah diatur dalam Pasal 5 ayat (6), (7), dan (8) UUPS yang intinya dinyatakan bahwa Bank Konvensional hanya dapat mengubah kegiatan usahanya berdasarkan Prinsip Syariah dengan izin Bank Indonesia. Lebih lanjut disebutkan bahwa Bank Umum Syariah dan Bank Pembiayaan Rakyat Syariah tidak dapat dikonversi menjadi Bank konvensional.

Secara teknis mengenai konversi telah diatur melalui PBI No. 11/15/PBI/2009 tentang Perubahan Kegiatan Usaha Bank Konvensional Menjadi Bank Syariah. Dalam praktiknya perubahan suatu bank konvensional menjadi bank syariah, biasanya didahului dengan proses pengambilalihan (akuisisi) oleh Bank Umum Konvensional terhadap Bank Konvensional lain. Hal ini terjadi antara lain pada kasus PT Bank Rakyat Indonesia (Persero) Tbk yang melakukan akuisisi PT Bank Jasa Arta (Bank BJA) yang kemudian dikonversi menjadi PT BRI Syariah ${ }^{39}$ dan PT Bank BCA yang mengakuisi PT Bank Utama Internasional Bank (Bank UIB) yang kemudian dikonversi menjadi PT Bank BCA Syariah. ${ }^{40}$

Pada tahun 2016, OJK sebagai lembaga yang mendapatkan pengalihan fungsi pengaturan dan pengawasan perbankan per 31 Desember 2013

39 BRI Syariah, t.t., Sejarah BRI Syariah, http://www.brisyariah.co.id/?q=sejarah, diakses 6 Januari 2015.

40 BCA Syariah, t.t., Sejarah Bank Syariah BCA, http://www.bcasyariah.co.id/profilkorporasi/sejarah/, diakses 6 Januari 2015. 
mengeluarkan POJK No. 64/POJK.03/2016 tentang Perubahan Kegiatan Usaha Bank Konvensional Menjadi Bank Syariah. Semangat dikeluarkannya POJK tersebut, antara lain berangkat dari pertimbangan bahwa bank syariah sebagai bagian dari sistem perbankan nasional perlu dikembangkan secara sehat dan kuat agar dapat memberikan pelayanan jasa perbankan bagi masyarakat yang salah satunya melalui perubahan kegiatan usaha bank konvensional menjadi bank syariah. Lebih lanjut ditegaskan bahwa perubahan kegiatan usaha dimaksud harus didukung dengan modal yang cukup dan manajemen yang professional sehingga dapat tercipta bank syariah yang sehat dan tangguh (sustainable). ${ }^{41}$ Substansi POJK a quo dan PBI No. 11/15/PBI/2009 pada prinsipnya sama, perbedaanya, antara lain terletak pada Pasal 4, yakni bahwa perubahan kegiatan usaha Bank Konvensional menjadi Bank Syariah hanya dapat dilakukan dengan izin OJK.

Munculnya regulasi tersebut menurut Penulis sejalan dengan prinsip kemudahan (taysir) yang menjadi salah satu prinsip fundamental dalam Hukum Islam. Guna memperoleh kemudahan, maka bank-bank konvensional besar memiliki kecenderungan mengambilalih bank konvensional yang relatif kecil dan mengkonversi kegiatan usahanya menjadi bank berdasarkan prinsip syariah. Langkah ini lebih mudah daripada mendirikan langsung Bank Umum Syariah, terutama ditinjau dari permodalan yang disyaratkan dan infrastruktur layanan perbankan. Hal ini juga bisa menjadi salah satu cara yang dapat ditempuh Bank Umum Konvensional untuk memisahkan UUS yang dimilikinya, antara lain yang telah dilakukan oleh PT Bank Rakyat Indonesia (Persero) Tbk, PT Bank Bukopin Tbk, dan PT Bank Tabungan Pensiunan Nasional Tbk. Penjelasan mengenai pemisahan UUS dimaksud Penulis pada bagian berikut.

\section{Pemisahan (Spin-off) Unit Usaha Syariah Bank Umum Konvensional}

Pemisahan adalah pemisahan usaha dari satu Bank menjadi dua badan usaha atau lebih, sesuai dengan ketentuan peraturan perundang-undangan. ${ }^{42}$

\footnotetext{
41 Lihat bagian menimbang huruf b dan c POJK No. 64/P0JK.03/2016 tentang Perubahan Kegiatan Usaha Bank Konvensional Menjadi Bank Syariah.

42 Lihat Undang-Undang R.I., No. 21 Tahun 2008, Perbankan Syariah, L.N.R.I. Tahun 2008 No. 94, Pasal 1 angka 32.
} 
Pemisahan (spin-off) yang merupakan kewajiban di atur dalam Ketentuan Peralihan Pasal 68 UUPS, yakni:

(1) Dalam hal Bank Umum Konvensional memiliki UUS yang nilai asetnya telah mencapai paling sedikit 50\% (lima puluh persen) dari total nilai aset bank induknya atau 15 (lima belas) tahun sejak berlakunya Undang-Undang ini, maka Bank Umum Konvensional dimaksud wajib melakukan Pemisahan UUS tersebut menjadi Bank Umum Syariah.

(2) Ketentuan lebih lanjut mengenai Pemisahan dan sanksi bagi Bank Umum Konvensional yang tidak melakukan Pemisahan sebagaimana dimaksud pada ayat (1) diatur dengan Peraturan Bank Indonesia.

Apabila Peneliti cermati, Pemisahan (spin-off) UUS dari BUK dalam rangka memenuhi kewajiban undang-undang tersebut dari perspektif otoritas adalah untuk mengakhiri keberadaan UUS yang merupakan Islamic window bagi BUK sehingga tercipta banyak BUS, sedangkan pemisahan sukarela yang telah dilaksanakan oleh beberapa BUK di Indonesia di samping dalam rangka memenuhi perintah undang-undang, juga keinginan memiliki BUS sebagai subsidiary atau anak perusahaan yang merupakan badan hukum mandiri.

Cara yang dapat dilaksanakan yakni melalui Model Akuisisi (Acquisition Model) berupa: (1) Spin-off dengan mengakuisisi BUS dan (2) Spin-off dengan mengakuisisi BUK yang kemudian dikonversi menjadi BUS. Cara lain yang dapat ditempuh adalah spin-off dengan mendirikan BUS baru oleh satu UUS BUK atau dengan pendirian BUS oleh lebih dari satu BUK yang memiliki UUS, cara terakhir ini dikenal dengan Model Murni (Pure Model). ${ }^{43}$

Dari beberapa cara spin-off tersebut hingga saat ini secara faktual yang sudah dilaksanakan adalah: Pertama, Model Murni (Pure Model), yakni dengan mendirikan BUS baru oleh satu UUS BUK sebagaimana dilakukan oleh PT. Bank Negara Indonesia (Persero) Tbk ${ }^{44}$ dan PT. Bank Jabar Banten Tbk ${ }^{45}$. Kedua, Model Akuisisi (Acquisition Model), khususnya spin-off dengan mengakuisisi BUK yang

43 KARIM Consulting Indonesia, 2014, Kajian Spin-Off Perbankan Syariah, www. karimconsulting.com, diakses 27 Februari 2016.

44 Hanafiah Ponggawa \& Partners, "Pengumuman Atas Ringkasan Rancangan Pemisahan Unit Usaha Syariah PT Bank Negara Indonesia (Persero) Tbk dengan Cara Pendirian Bank Umum Syariah", Jakarta, 12 Agustus 2009.

45 BJB Syariah, "Sekilas BJB Syariah", http://bjbsyariah.co.id/tentang-bjb-syariah/sekilas-bjbsyariah/, diakses tanggal 15 Agustus 2017. 
kemudian dikonversi menjadi BUS sebagaimana yang telah dilaksanakan oleh PT. Bank Rakyat Indonesia (Persero) Tbk ${ }^{46}$, PT Bank Bukopin Tbk ${ }^{47}$, dan PT Bank Tabungan Pensiunan Nasional Tbk ${ }^{48}$.

Pertimbangan adanya pemisahan UUS BUK ke dalam BUS dapat dilihat secara makro maupun secara mikro. Pertimbangan makro adalah keinginan dari Pemerintah untuk memisahkan tata kelola syariah secara kelembagaan dengan tata kelola perbankan konvensional melalui pembentukan BUS atau pengalihan hak dan kewajiban UUS BUK ke dalam BUS yang sudah ada guna mencapai tujuan akhir berupa peningkatan kepercayaan masyarakat terhadap industri perbankan syariah. Pertimbangan utama secara mikro dari masing-masing BUK yang memisahkan UUS adalah dalam rangka mencapai fokus dan independensi, yakni BUS fokus dan independen dalam tata kelola perbankan syariah, sementara BUK kembali fokus kepada bisnis inti berupa aktivitas perbankan konvensional. 49

Tenggat waktu pemisahan (spin-off) apabila dilihat dari Pasal 68 ayat (1) UUPS adalah 15 (lima belas) tahun sejak berlakunya undang-undang ini, artinya tahun 2023. Namun demikian, Penulis belum menemukan adanya roadmap pemisahan (spin-off) UUS yang merupakan salah satu bagian dari isu dan kebijakan sebagaimana tertuang dalam Roadmap Perbankan Syariah, yakni dalam rangka memperkuat permodalan dan skala usaha, serta memperbaiki efisiensi.

Malaysia tidak menempuh kebijakan berupa kewajiban pemisahan UUS seperti di Indonesia. Dalam fase ketiga yang dikenal dengan "The dominance of Islamic financial institutions over the conventional", otoritas justru lebih fokus pada menciptakan beberapa pra-kondisi yang diperlukan (the necessary of preconditions), antara lain: “( a) Islamic finance will have to be developed into a genuine

46 PT Bank Rakyat Indonesia (Persero) Tbk, "Tata Kelola dan Inovasi: Landasan Kami Untuk Pertumbuhan Berkelanjutan", Laporan Tahunan PT Bank Rakyat Indonesia (Persero) Tbk 2012, Jakarta, 2012, hlm., 212.

47 PT Bank Bukopin, " Meraih Peluang dan Pertumbuhan Bersama Bank Bukopin”, Laporan Tahunan PT Bank Bukopin 2009, Jakarta, 2009, hlm., 116.

48 PT BTPN Syariah, "Memberi Kesempatan Tumbuh", Laporan Tahunan PT BTPN Syariah 2014, Jakarta, 2014, hlm., 182.

49 Khotibul Umam, "Transformasi Unit Usaha Syariah ke dalam Bank Umum Syariah di Indonesia”. Disertasi pada Prodi S3 Ilmu Hukum 2018, Universitas Gadjah Mada, Yogyakarta, hlm., 436. 
parallel system in the international arena; and (b) ... in the third phase leaders in the capital market will have to play a prominent role." Hingga saat ini Malaysia tetap mempertahankan lembaga keuangan Islam paralel terhadap sistem konvensional, artinya tetap boleh lembaga keuangan konvesional secara bersamaan juga memberikan layanan syariah. ${ }^{50}$

Dengan demikian dapat Penulis tegaskan bahwa ketiga lembaga hukum berupa KPJKS, Konversi Bank Konvensional, dan Pemisahan UUS BUK merupakan salah satu upaya dari pemerintah secara top-down untuk mengembangkan sistem perbankan syariah Indonesia yang mampu memenuhi kebutuhan masyarakat akan jasa perbankan modern dengan tetap memenuhi prinsip syariah. Hukum dalam arti peraturan perundang-undangan yang diberikan oleh pemerintah (otoritas) dapat memainkan perannya sebagai sarana pembangunan sebagaimana yang menjadi substansi utama dari Teori Hukum Pembangunan.

\section{Penutup}

Hukum berperan dalam pembangunan sistem perbankan syariah di Indonesia, baik pada tahap perkenalan, tahap pengakuan, dan tahap pemurnian. Pertama, dengan diundangkannya UUP 1992 menunjukkan bahwa Pemerintah melalui sarana hukum melegitimasi berdirinya bank bagi hasil dan sekaligus memperkenalkan kepada masyarakat bahwa kegiatan intermediasi keuangan dapat dilaksanakan baik berdasarkan sistem bunga bank atau sistem bagi hasil. Kedua, dengan diundangkannya UUP 1998 menjadi legitimasi bagi Bank Umum Konvensional memberikan layanan syariah dengan cukup mendirikan UUS. Karena kemudahan pemberian layanan syariah via peraturan perundangundangan ternyata masih menyisakan sejumlah persoalan, terutama dari sisi pengaturan dan kelembagaan yang oleh sebagian masyarakat dianggap berdampak pada belum optimalnya bank syariah dalam melaksanakan prinsip syariah, terutama dari layanan syariah yang dilakukan oleh entitas konvensional, maka maka Pemerintah kemudian mengundangkan UUPS. Ketiga, dengan diundangkannya undang-undang a quo memunculkan paling tidak tiga lembaga

${ }^{50}$ Zaharuddin Abd. Rahman, Supra No 7, hlm., 4-5. 
hukum berupa KPJKS, Konversi Bank Konvensional, dan Pemisahan UUS BUK yang merupakan salah satu upaya dari pemerintah (otoritas) secara top-down untuk mengembangkan sistem perbankan syariah Indonesia yang mampu memenuhi kebutuhan masyarakat akan jasa perbankan modern dengan tetap memenuhi prinsip syariah. Hukum dalam arti peraturan perundang-undangan dengan demikian memainkan perannya sebagai sarana pembangunan sebagaimana yang menjadi substansi utama dari Teori Hukum Pembangunan.

\section{Daftar Pustaka}

\section{Buku:}

Angelo M. Venardos, Islamic Banking \& Finance in South-East Asia : Its Development \& Future, World Scientific Publishing, New Jersey-LondonSingapore-Beijing-Shanghai-Hongkong-Taipei-Chennai, 2005.

Bank Muamalat Indonesia, Laporan Tahunan BMI 1995, BMI, Jakarta, Jakarta, 1995.

Bank Syariah Mandiri, Laporan Tahunan 2013 PT Bank Syariah Mandiri, Bank Syariah Mandiri, Jakarta, 2013.

Bank Syariah Mega, Laporan Tahunan Bank Mega Syariah 2011, Bank Mega Syariah, Jakarta, 2011.

Departemen Perbankan Syariah, "Roadmap Perbankan Syariah Indonesia 20152019”, Otoritas Jasa Keuangan, 2015.

Hanif Amali Rivai dkk, "Identifikasi Faktor Penentu Keputusan Konsumen Dalam Memilih Jasa Perbankan : Bank Syariah Vs Bank Konvensional”, Penelitian Bank Indonesia, Jakarta, 6 Maret 2016.

Hirsanuddin, Hukum Perbankan Syariah di Indonesia : Pembiayaan Bisnis dengan Prinsip Kemitraan, Genta Press, Yogyakarta, 2008.

Institut Bankir Indonesia, Konsep, Produk dan Implementasi Operasional Bank Syariah, Penerbit Djambatan, Jakarta, 2001.

Muchamad Parmudi, Sejarah \& Doktrin Bank Islam, Kutub, Yogyakarta, 2005 
Muhammad Syafi'i Antonio, Bank Syariah dari Teori ke Praktik, Gema Insani Press dan Tazkia Cendekia, Jakarta, 2001.

Nina Pane, Rekam Jejak Kebangsaan Mochtar Kusuma-atmadja, Penerbit Buku Kompas, Jakarta, 2015.

Peter Mahmud Marzuki, 2005, Penelitian Hukum: Edisi Revisi, Kencana, Jakarta

PT Bank Bukopin, " Meraih Peluang dan Pertumbuhan Bersama Bank Bukopin”, Laporan Tahunan PT Bank Bukopin 2009, Jakarta, 2009.

PT Bank Rakyat Indonesia (Persero) Tbk, "Tata Kelola dan Inovasi: Landasan Kami Untuk Pertumbuhan Berkelanjutan", Laporan Tahunan PT Bank Rakyat Indonesia (Persero) Tbk 2012, Jakarta, 2012.

PT BTPN Syariah, "Memberi Kesempatan Tumbuh", Laporan Tahunan PT BTPN Syariah 2014, Jakarta, 2014.

Rifki Ismal, The Indonesian Islamic Banking: Theory and Practices, Gramata Publishing, Jakarta, 2011.

Shidarta (ed), Mochtar Kusuma-atmadja dam Teori Hukum Pembangunan: Eksistensi dan Implikasi, Epsitema Institute dan Huma, Jakarta, 2012.

Sutan Remy Sjahdeini, Perbankan Syariah: Produk-Produk dan Aspek-Aspek Hukumnya, Kencana Prenada Media, Jakarta, 2014.

Wirdyaningsih-dkk, Bank dan Asuransi Islam di Indonesia, Kerja sama Kencana Media Group dan Fakultas Hukum Universitas Indonesia, Jakarta, 2005.

Zaharuddin Abd. Rahman, Contemporary Islamic Finance Architecture, IBFIM, Kuala Lumpur, Malaysia, 2014.

Zainul Arifin, Memahami Bank Syariah: Lingkup, Peluang, dan Prospek, Alvabet, Jakarta, 1999.

Referensi Yang Tidak Dipublikasi:

Abdul Ghofur Anshori, Kuliah Perdana Magister Hukum Bisnis dan Kenegaraan, Perkembangan Hukum, Kelembagaan, dan Operasional Perbankan Syariah di Indonesia, Fakultas Hukum UGM, Yogyakarta, 14 Juni 2008.

\section{Web Dokumen:}

BCA Syariah, Sejarah Bank Syariah BCA, http://www.bcasyariah.co.id/profilkorporasi/sejarah/, diakses 6 Januari, 2015.

BJB Syariah, "Sekilas BJB Syariah", http://bjbsyariah.co.id/tentang-bjbsyariah/sekilas-bjb-syariah/, diakses tanggal 15 Agustus, 2017.

BRI Syariah, t.t., Sejarah BRI Syariah, http://www.brisyariah.co.id/?q=sejarah, diakses 6 Januari, 2015.

KARIM Consulting Indonesia, 2014, Kajian Spin-Off Perbankan Syariah, www. karimconsulting.com, tanggal akses 27 Februari, 2016.

Otoritas Jasa Keuangan, Kebijakan Pengembangan Perbankan Syariah di Indonesia, Otoritas Jasa Keuangan, Jakarta, http://ojk.go.id/bank-syariah, diakses 18 Desember, 2014.

Statistik Perbankan Syariah September 2019, https://www.ojk.go.id/id/kanal/syariah/data-dan-statistik/statistikperbankan-syariah/Documents/Pages/Stastistik-Perbankan-Syariah--September- 
2019/Statistik\%20Perbankan\%20Syariah\%20September\%202019.pdf, diakses 16 Desember, 2019.

Laporan Perkembangan Keuangan Syariah Tahun 2013, https://www.ojk.go.id/id/data-dan-statistik/ojk/Pages/laporanperkembangan-keuangan-syariah-2013.aspx, diakses 6 Januari, 2015.

Peri Umar Farouk, t.t. Sejarah Hukum Perbankan Syariah Indonesia, http://www.sharialearn.com/ diakses 9 Desember, 2014.

\section{Peraturan Perundang-undangan:}

Undang-Undang R.I., Nomor 21 Tahun 2008, Perbankan Syariah, L.N.R.I. Tahun 2008 No. 94.

Undang-Undang R.I., No. 10 Tahun 1998, Perubahan Atas Undang-Undang Nomor 7 Tahun 1992 tentang Perbankan, , L.N.R.I. Tahun 1998 No. 182.

Peraturan Bank Indonesia No. 10/32/PBI/2008, Komite Perbankan Syariah, L.N.R.I Tahun 2008 No. 179 DPbS, Tambahan L.N.R.I. No. 4927.

Peraturan Bank Indonesia No. 9/19/PBI/2007, Pelaksanaan Prinsip Syariah Dalam Kegiatan Penghimpunan Dana Dan Penyaluran Dana Serta Pelayanan Jasa Bank Syariah, L.N.R.I. Tahun 2007 No. 165, Tambahan Lembaran Negara Republik Indonesia Nomor 4793.

Peraturan Bank Indonesia No. 7/46/PBI/2005, Akad Penghimpunan dan Penyaluran Dana Bagi Bank Yang Melaksanakan Usaha Berdasarkan Prinsip Syariah, L.N.R.I. Tahun 2005 No. 124 DPbS, Tambahan Lembaran Negara Republik Indonesia Nomor 4563.

\section{Lain-lain:}

Hanafiah Ponggawa \& Partners, "Pengumuman Atas Ringkasan Rancangan Pemisahan Unit Usaha Syariah PT Bank Negara Indonesia (Persero) Tbk dengan Cara Pendirian Bank Umum Syariah", Jakarta, 12 Agustus 2009.

Khotibul Umam, "Transformasi Fatwa Dewan Syariah Nasional - Majelis Ulama Indonesia ke dalam Regulasi Keuangan Syariah", Laporan Penelitian Doktor 2019 yang belum dipublikasikan, Unit Riset dan Publikasi Fakultas Hukum UGM, Yogyakarta, 2019.

"Transformasi Unit Usaha Syariah ke dalam Bank Umum Syariah di Indonesia". Disertasi pada Prodi S3 Ilmu Hukum 2018, Universitas Gadjah Mada, Yogyakarta. 